Haya: The Saudi Journal of Life Sciences

Abbreviated Key Title: Haya Saudi J Life Sci ISSN 2415-623X (Print) |ISSN 2415-6221 (Online) Scholars Middle East Publishers, Dubai, United Arab Emirates Journal homepage: https://saudijournals.com/sjls

Original Research Article

\title{
Association of Blood Pressure with Fruit Chaat Likeness
}

Muhammad Imran Qadir, Muazam Jelani, Jawaria Iftikhar*

Institute of Molecular Biology and Biotechnology, Bahauddin Zakariya University, Multan, Pakistan

DOI: $\underline{10.36348 / \mathrm{sj} 1 \mathrm{ls} .2020 . \mathrm{v} 05 \mathrm{i} 08.001}$

| Received: 06.07.2020 | Accepted: 24.07.2020 | Published: 19.08.2020

*Corresponding author: Jawaria Iftikhar

Abstract

Objective of the present study was to analyze association of blood pressure with fruit chaat likeness. A questionnaire was prepared about the fruit chaat likeliness. 200 participants were took part in this project. All these people were the students of postgraduate class. First of all we measured the blood pressure of all the participants and then took their views about the likeliness of fruit chaat. The present study showed that blood pressure and fruit chaat likeness have no scientific relationship.

Keywords: Blood pressure, systolic, heart, force, health.

Copyright @ 2020: This is an open-access article distributed under the terms of the Creative Commons Attribution license which permits unrestricted use, distribution, and reproduction in any medium for non-commercial use (NonCommercial, or CC-BY-NC) provided the original author and source are credited.

\section{INTRODUCTION}

For the normal function of the body, oxygen is very necessary. This oxygen is provided by the blood. When heart is beat than it pushes the blood away from it to the other parts of the body. When blood flows from the blood vessels then it exerts a force on the walls of vessels. This force is known as blood pressure. Blood pressure has two levels one is systolic and other is diastolic. The systolic pressure is always high from the diastolic. Sometimes blood pressure is very high because blood exerts maximum force on the blood vessels. If blood pressure is high from the normal value than chances of disease increased specially heart attack. Sometimes blood exerts minimum force on the blood vessels. It is known as low blood pressure. The normal value of blood pressure is $120 / 80 \mathrm{mmHg}$ [1].

Fruit chaat is a dish which is made of different types of fruits. It is also considered as a sweet dish. Mostly it is served with the fruit juices. Many people like to eat fruit chaat because it provides energy to our body. So, fruit chaat is very necessary for the health. People also made it in the houses. In wedding ceremonies, it is become the culture to serve the guests with fruit chaat before meal. Many people found of it. Different types of fruits with different taste are mixed to form fruit chaat [2].

Objective of the present study was to analyze association of blood pressure with fruit chaat likeness.

\section{MATERAILS \& METHOD Measurement of Blood Pressure}

A force which is exerts by the blood on the walls of blood vessels is called blood pressure. Sphygmomanometer is used to measure the blood pressure. The normal value of blood pressure is $120 / 80 \mathrm{mmHg}$.

\section{Project Design}

A questionnaire was prepared about the fruit chaat likeliness. 200 participants were took part in this project. All these people were the students of postgraduate class. First of all we measured the blood pressure of all the participants and then took their views about the likeliness of fruit chaat.

Statistical Analysis: Statistical analysis was performed by MS Excel.

\section{RESULT \& DISCUSSION}

200 participants were took part in this project. Sphygmomanometer is used to measure the blood pressure and correlated it with the likeness of fruit chaat. From the result it was cleared that the people with high blood pressure mostly liked the fruit chaat while people with lower blood pressure not liked the fruit chaat mostly. $p>0.05$ value is significant for the $t$ test. 
Table-1: Relation of male blood pressure (Mean \pm SD) with fruit chaat likeness

\begin{tabular}{|l|l|l|l|}
\hline \multicolumn{2}{|c|}{ Fruit chaat likeness } & \multicolumn{2}{c|}{ Fruit chaat dislikeness } \\
\hline $\begin{array}{l}\text { Male systolic blood } \\
\text { pressure Mean } \pm \text { SD }\end{array}$ & $\begin{array}{l}\text { Male diastolic blood } \\
\text { pressure Mean } \pm \text { SD }\end{array}$ & $\begin{array}{l}\text { Male systolic blood } \\
\text { pressure Mean } \pm \text { SD }\end{array}$ & $\begin{array}{l}\text { Male diastolic blood } \\
\text { pressure Mean } \pm \text { SD }\end{array}$ \\
\hline $16.93 \pm 2.98$ & $73.38 \pm 9.38$ & $11.47 \pm 8.48$ & $77.10 \pm 20.56$ \\
\hline
\end{tabular}

Table-2: Relation of female blood pressure (Mean \pm SD) with fruit chaat likeness

\begin{tabular}{|l|l|l|l|}
\hline \multicolumn{2}{|c|}{ Fruit chaat likeness } & \multicolumn{2}{c|}{ Fruit chaat dislikeness } \\
\hline $\begin{array}{l}\text { Female systolic blood } \\
\text { pressure Mean } \pm \text { SD }\end{array}$ & $\begin{array}{l}\text { Female diastolic blood } \\
\text { pressure Mean } \pm \text { SD }\end{array}$ & $\begin{array}{l}\text { Female systolic blood } \\
\text { pressure Mean } \pm \text { SD }\end{array}$ & $\begin{array}{l}\text { Female diastolic blood } \\
\text { pressure Mean } \pm \text { SD }\end{array}$ \\
\hline $116.93 \pm 12.33$ & $75.52 \pm 11.64$ & $113.10 \pm 15.01$ & $73.65 \pm 10.53$ \\
\hline \multicolumn{2}{|c|}{$p>0.05$ (non-significant) }
\end{tabular}

Table-3: Relation of both male and female blood pressure (Mean \pm SD) with fruit chaat likeness

\begin{tabular}{|l|l|l|l|}
\hline \multicolumn{2}{|c|}{ Fruit chaat likeness } & \multicolumn{2}{c|}{ Fruit chaat dislikeness } \\
\hline $\begin{array}{l}\text { Male systolic blood } \\
\text { pressure Mean } \pm \text { SD }\end{array}$ & $\begin{array}{l}\text { Male diastolic blood } \\
\text { pressure Mean } \pm \text { SD }\end{array}$ & $\begin{array}{l}\text { Female systolic blood } \\
\text { pressure Mean } \pm \text { SD }\end{array}$ & $\begin{array}{l}\text { Female diastolic blood } \\
\text { pressure Mean } \pm \text { SD }\end{array}$ \\
\hline $127.08 \pm 15.63$ & $74.00 \pm 11.81$ & $116.39 \pm 12.33$ & $75.26 \pm 11.47$ \\
\hline
\end{tabular}
$p>0.05$ (non-significant)

\section{CONCLUSION}

The present study showed that blood pressure and fruit chaat likeness have no scientific relationship [3-10].

\section{REFERENCES}

1. Qadir, M. I., \& Saleem, A. (2018). Awareness about ischemic heart disease in university biotechnology students. Glo Adv Res J Med Medical Sci, 7(3), 59-61.

2. Qadir, M. I., \& Ishfaq, S. (2018). Awareness about hypertension in biology students. Int $J$ Mod Pharma Res, 7(2), 8-10.

3. Qadir, M. I. Mehwish (2018) Awareness about psoriasis disease. Int J Mod Pharma Res, 7(2), 1718.

4. Qadir, M. I., \& Shahzad, R. (2018). Awareness about obesity in postgraduate students of biotechnology. Int J Mod Pharma Res, 7(2), 1416.
5. Qadir, M. I., \& Rizvi, M. (2018). Awareness about thalassemia in post graduate students. MOJ Lymphology \& Phlebology, 2(1), 14-16.

6. Qadir, M., \& Ghalia, B. A. (2018). Awareness survey about colorectal cancer in students of $\mathrm{M}$. Phil Biotechnology at Bahauddin Zakariya University, Multan, Pakistan. Nov Appro in Can Study, 1(3): NACS.000514.

7. Qadir, M., \& Saba, G. (2018). Awareness about intestinal cancer in university student. Nov Appro in Can Study, 1(3), 000515.

8. Bedson, S. P., \& Bland, J. O. W. (1932). A morphological study of psittacosis virus, with the description of a developmental cycle. British journal of experimental pathology, 13(5), 461.

9. Meyer, K. F. (1942). The ecology of psittacosis and ornithosis. Medicine, 21(2), 175.

10. Qadir, M. I., \& Javid, A. (2018). Awareness about Crohn's Disease in biotechnology students. Glo Adv Res J Med Medical Sci, 7(3), 062-064. 